\title{
Telanthera Ficoidea - A New Source of Natural Dye for Mulberry Silk
}

\author{
Ms. Pomima Duarah \\ College of Home Science, Department of Clothing and Textiles.Assam Agricultural University, Jorhat-13, \\ Assam
}

\section{Introduction}

Environmental considerations are now becoming an additional importantfactor during the selection of consumer goods including textiles all over the world. The world has become increasingly aware of the environmental issues through pollution and waste disposal. So, interest in natural products is gaining importance throughout the world and people are becoming aware of the need for eco-friendly materials. Thus, revival of the use of natural dyes world-wide is primarily due to the increasing environmental consciousness today. Naturally occurring materials are non-toxic, biodegradable and non-carcinogenic. Natural dyeing is the way to save environment. Natural dyes make an important contribution to fabric decoration by producing various shades by the use of mordants and different dyeing methods.

For this study, leaves and stems of Telanthera ficoidea were used to dye mulberry silk fabric. Telanthera ficoidea plant is a semi erect herb of deep purple colour.

It is cultivated as a hedge for lawn decoration and can be propagated easily.

The study was taken up with the following objectives :

1. To dye silk fabric with the selected dye under varying conditions.

2. To study the fastness properties of the dye.

\section{Materials and Methods}

The specific dye-bearing parts (leaf and stem) of Telanthera ficoidea plant were dried and powdered. The powdered material was used as dye for dyeing of mulberry silk fabric of plain weave. Silk needs to be degummed before dyeing. So, degumming was done with the help of $0.25 \mathrm{gm} / \mathrm{litre}$ of $\mathrm{Na}_{2} \mathrm{CO}_{3}, 2 \%$ soap/litre and by maintaining the liquor ratio $1: 40$ at a temperature of $90^{\circ} \mathrm{C}$ for 90 minutes. The fabric was squeezed, rinsed thoroughly under running

water and dried in shade. The nomenclature of the samples was done according to the treatment. The three variables for the study were dye extraction method, mordant and mordanting method. Fabric samples were dyed under the conditions of temperature $90^{\circ} \mathrm{C}$, time $45 \mathrm{~min}$. and $\mathrm{M}: \mathrm{L}:: 1: 40$.

Extraction of dye: The dye was extracted in alkaline and acidic media.

Alkaline method: In order to select the amount of alkali for dye extraction, tests were carried out and the concentration of $\mathrm{Na}_{2} \mathrm{CO}_{3}$ selected was $0.5 \mathrm{gm} / 100 \mathrm{ml}$. The alkalinity of the liquor was maintained at $\mathrm{pH} 9-10$. The concentration selected was based on the optical density value and percent dye absorption.

Acidic method :In order to select the amount of acid for dye extraction, tests were carried out and the concentration of $\mathrm{HCl}$ selected was $1.0 \% / 100 \mathrm{ml}$. The $\mathrm{pH}$ of the acidic liquor was maintained at $\mathrm{pH} 2-3$. The concentration selected was based on the optical value and percent dye absorption.

Mordants :The mordants selected were alum (metallic mordant) and tea (natural mordants). Tests were carried out to select the concentration of the mordants for dyeing based on optical density and percent dye absorption. The concentration of alum selected was $15 \mathrm{gm}$ per $100 \mathrm{gm}$ of fabric and the concentration of tea selected was $10 \mathrm{gm}$ per $100 \mathrm{gm}$ of fabric.

Mordanting :All three mordanting methods viz., pre, simultaneous and post mordanting methods were used.

Dyeing method: The calculated amount of extracted dye liquor was taken as per the material to liquor ratio. The material to liquor ratio (M : L) was finalized at $1: 40$ for dyeing. The dyeing time selected was 45 minutes, maintaining a temperature of $90^{\circ} \mathrm{C}$. The percentage of dye absorption by the fabric sample at a particular wave length $(580 \mathrm{~nm})$ was estimated as

OD before dyeing - OD after dyeing

Percent dye absorption $=$

O.D. before dyeing 


\section{Result \& Discussion}

The shades obtained by mulberry silk fabric dyed with Telanthera ficoidea along with mordant Alum and tea were cream, mid cream, stone brown, golden brown, copper brown, dark brown. Findings of the fastness properties were evaluated with the help of a Gray scale for fastness grade after dyeing. assessed for their colourfastness with the help of the following tests.

(i) Colourfastness to sunlight,

(ii) Colourfastness to washing

(iii) Colourfastness to pressing (dry and wet)

(iv) Colourfastness to crocking (dry and wet)

(v) Colourfastness to perspiration (Alkaline and acidic)

These test were done by the standard procedures and the effect was expressed and defined with reference to the International Gray Scale by grading the sample 1-5. All the samples obtained a grade of 4 to 5, indicating that all the samples showed fair-good colourfastness to sunlight, washing, pressing (wet and dry), crocking (wet and dry) and

perspiration (alkaline and acidic). In respect of colourfastnes properties, the highest mean score of 4.975 was obtained by the sample dyed with dye extracted in alkaline medium using tea as mordant in simultaneous mordanting method (8) $\mathrm{A}_{1} \mathrm{M}_{2} \mathrm{~S}$. The lowest mean score of 4.700 in respect of colour fastness was obtained by the sample (2) $\mathrm{A}_{1}($ Table 1$)$ dyed with dye extracted in alkaline medium without any mordant.

Table 1. Colour fastness grades for dyed samples

\begin{tabular}{|c|c|c|c|c|c|c|c|c|c|c|c|c|c|c|c|c|c|c|c|c|c|c|c|c|c|}
\hline \multirow{5}{*}{$\begin{array}{c}\text { Sl. } \\
\text { No. }\end{array}$} & \multirow[t]{5}{*}{ Sample } & \multirow{5}{*}{$\begin{array}{c}\text { Mordant } \\
\text { used }\end{array}$} & \multirow{5}{*}{$\begin{array}{c}\text { Dye } \\
\text { extraction } \\
\text { medium }\end{array}$} & \multirow{5}{*}{ Mordanting } & \multicolumn{20}{|c|}{ Fastness properties } & \multirow[t]{5}{*}{ Mean score } \\
\hline & & & & & \multirow[t]{4}{*}{ Sunlight } & \multicolumn{3}{|c|}{ Washing } & \multicolumn{6}{|c|}{ Crocking } & \multicolumn{4}{|c|}{ Pressing } & \multicolumn{6}{|c|}{ Perspiration } & \\
\hline & & & & & & \multirow[t]{3}{*}{$\mathrm{CC}$} & \multicolumn{2}{|c|}{$\mathrm{CS}$} & \multicolumn{3}{|c|}{ Dry } & \multicolumn{3}{|c|}{ Wet } & \multicolumn{2}{|c|}{ Dry } & \multicolumn{2}{|c|}{ Wet } & \multicolumn{3}{|c|}{ Acidic } & \multicolumn{3}{|c|}{ Alkaline } & \\
\hline & & & & & & & \multirow[t]{2}{*}{$\mathrm{S}$} & \multirow[t]{2}{*}{$\mathrm{C}$} & \multirow[t]{2}{*}{$\mathrm{CC}$} & \multicolumn{2}{|c|}{$\mathrm{CS}$} & \multirow[t]{2}{*}{$\mathrm{CC}$} & \multicolumn{2}{|c|}{$\mathrm{CS}$} & $\mathrm{CC}$ & $\mathrm{CS}$ & $\mathrm{CC}$ & $\mathrm{CS}$ & $\mathrm{CC}$ & $\mathrm{C}$ & $\mathrm{S}$ & $\mathrm{CC}$ & $\mathrm{C}$ & $\mathrm{S}$ & \\
\hline & & & & & & & & & & $\mathrm{S}$ & $\mathrm{C}$ & & $\mathrm{S}$ & $\mathrm{C}$ & & & & & & $\mathrm{S}$ & $\mathrm{C}$ & & $\mathrm{S}$ & $\mathrm{C}$ & \\
\hline & $\mathrm{O}$ & & & & & & & & & & & & & & & & & & & & & & & & \\
\hline & $A_{1}$ & & Alkaline & & $4-5$ & 4 & 4 & 5 & 5 & 5 & 5 & $4-5$ & $\begin{array}{c}4- \\
5\end{array}$ & $\begin{array}{c}4- \\
5\end{array}$ & 5 & 5 & 5 & 5 & $4-5$ & $\begin{array}{c}4- \\
5\end{array}$ & 5 & $4-5$ & $4-5$ & 5 & 4.700 \\
\hline & $\mathrm{A}_{2}$ & & Acidic & & $4-5$ & 5 & 5 & 5 & 5 & 5 & 5 & $4-5$ & $\begin{array}{c}4- \\
5\end{array}$ & $\begin{array}{c}4- \\
5\end{array}$ & 5 & 5 & 5 & 5 & 5 & 5 & 5 & 5 & 5 & 5 & 4.900 \\
\hline & $\mathrm{A}_{1} \mathrm{M}_{1} \mathrm{P}_{1}$ & Alum & Alkaline & Pre & 4 & 5 & 5 & 5 & 5 & 5 & 5 & 4 & 4 & 4 & 5 & 5 & 5 & 5 & 5 & 5 & 5 & 5 & 5 & 5 & 4.800 \\
\hline & $\mathrm{A}_{1} \mathrm{M}_{1} \mathrm{~S}$ & Alum & Alkaline & Sim & 4 & 5 & 5 & 5 & 5 & 5 & 5 & 5 & 5 & 5 & 5 & 5 & 5 & 5 & 5 & 5 & 5 & 5 & 5 & 5 & 4.950 \\
\hline & $\mathrm{A}_{1} \mathrm{M}_{1} \mathrm{P}_{2}$ & Alum & Alkaline & Post & 4 & 5 & 5 & 5 & 5 & $\begin{array}{c}4- \\
5\end{array}$ & $\begin{array}{l}4- \\
5\end{array}$ & $4-5$ & $\begin{array}{c}4- \\
5\end{array}$ & $\begin{array}{c}4- \\
5\end{array}$ & 5 & 5 & 5 & 5 & 5 & $\begin{array}{c}4- \\
5\end{array}$ & $\begin{array}{l}4- \\
5\end{array}$ & $4-5$ & $4-5$ & 5 & 4.725 \\
\hline & $\mathrm{A}_{1} \mathrm{M}_{2} \mathrm{P}_{1}$ & Tea & Alkaline & Pre & $4-5$ & 5 & 5 & 5 & 5 & 5 & 5 & $4-5$ & $\begin{array}{c}4- \\
5\end{array}$ & $\begin{array}{c}4- \\
5\end{array}$ & 5 & 5 & 5 & 5 & 5 & 5 & 5 & 5 & 5 & 5 & 4.900 \\
\hline & $\mathrm{A}_{1} \mathrm{M}_{2} \mathrm{~S}$ & Tea & Alkaline & Sim & $4-5$ & 5 & 5 & 5 & 5 & 5 & 5 & 5 & 5 & 5 & 5 & 5 & 5 & 5 & 5 & 5 & 5 & 5 & 5 & 5 & 4.975 \\
\hline & $\mathrm{A}_{1} \mathrm{M}_{2} \mathrm{P}_{2}$ & Tea & Alkaline & Post & $4-5$ & 5 & 5 & 5 & 5 & 5 & 5 & $4-5$ & $\begin{array}{c}4- \\
5\end{array}$ & $\begin{array}{c}4- \\
5\end{array}$ & 5 & 5 & $4-5$ & $4-5$ & 5 & 5 & 5 & $4-5$ & $4-5$ & 5 & 4.800 \\
\hline & $\mathrm{A}_{2} \mathrm{M}_{1} \mathrm{P}_{1}$ & Alum & Acidic & Pre & $4-5$ & 5 & 5 & 5 & 5 & 5 & 5 & $4-5$ & $\begin{array}{c}4- \\
5\end{array}$ & $\begin{array}{c}4- \\
5\end{array}$ & 5 & 5 & 5 & 5 & 5 & $\begin{array}{c}4- \\
5\end{array}$ & $\begin{array}{l}4- \\
5\end{array}$ & 5 & 5 & 5 & 4.850 \\
\hline & $\mathrm{A}_{2} \mathrm{M}_{1} \mathrm{~S}$ & Alum & Acidic & Sim & $4-5$ & $4-5$ & $4-5$ & 5 & 5 & 5 & 5 & $4-5$ & $\begin{array}{c}4- \\
5\end{array}$ & $\begin{array}{c}4- \\
5\end{array}$ & 5 & 5 & 5 & 5 & 5 & 4 & 4 & 5 & 5 & 5 & 4.750 \\
\hline & $\mathrm{A}_{2} \mathrm{M}_{1} \mathrm{P}_{2}$ & Alum & Acidic & Post & 4 & $4-5$ & $4-5$ & 5 & 5 & 5 & 5 & 5 & 5 & 5 & 5 & 5 & 5 & 5 & 5 & 5 & 5 & 5 & 5 & 5 & 4.900 \\
\hline & $\mathrm{A}_{2} \mathrm{M}_{2} \mathrm{P}_{1}$ & Tea & Acidic & Pre & $4-5$ & 5 & 5 & 5 & 5 & $\begin{array}{c}4- \\
5\end{array}$ & $\begin{array}{c}4- \\
5\end{array}$ & 4 & 4 & 4 & 5 & 5 & $4-5$ & $4-5$ & 5 & 5 & 5 & 5 & 5 & 5 & 4.725 \\
\hline & $\mathrm{A}_{2} \mathrm{M}_{2} \mathrm{~S}$ & Tea & Acidic & Sim & $4-5$ & 5 & 5 & 5 & 5 & $\begin{array}{c}4- \\
5\end{array}$ & $\begin{array}{l}4- \\
5\end{array}$ & $4-5$ & $\begin{array}{c}4- \\
5\end{array}$ & $\begin{array}{c}4- \\
5\end{array}$ & 5 & 5 & $4-5$ & $4-5$ & 5 & 5 & 5 & 5 & 5 & 5 & 4.800 \\
\hline & $\mathrm{A}_{2} \mathrm{M}_{2} \mathrm{P}_{2}$ & Tea & Acidic & Post & $4-5$ & 5 & 5 & 5 & 5 & $\begin{array}{c}4- \\
5\end{array}$ & 4- & 4 & 4 & 4 & 5 & 5 & 5 & 5 & 5 & 5 & 5 & 5 & 5 & 5 & 4.775 \\
\hline
\end{tabular}

CC : Colour change; $\quad$ CS : Colour staining; $\quad$ S : Silk; $\quad$ C : Cotton* Fas

Pre : Pre-mordanting, Sim : Simultaneous mordanting; Post : Post mordanting

Fastness grade (1 : Very poor, 2 : Poor, 3 : Fair, 4 : Very fair, 5 : Good) 


\section{Conclusion}

On the basis of experimental results, it can be concluded that the leaves and stems of Telanthera ficoidea can be successfully used for dyeing of mulberry silk fabric in the presence of mordants Alum and Tea. The shades obtained ranged from cream to dark brown each having good colour fastness to sunlight, washing, pressing (dry and wet), crocking (dry and wet) and perspiration (alkalial and acidic).

\section{Reference}

[1]. Agarwal, S. and Gupta, K. C. (2005). Optimization of dyeing conditions for natural dye - Madder roots (Rubia corifolia). Tex. Trends XLVIII:24-27.

[2]. Bhal, D. and Gupta, K. C. (1988). Development of dyeing process of silk with natural dye cutch. Colourage 33(22):22-24

[3]. Bisht, B. G. and Goel, A. (1999). Dyeing of natural fibre - Bhimal with natural dye. Kilmora. Tex. Trends. 42(5):33-35.

[4]. Bhuyan, R.; Saikia, D. C. and Saikia, C. N. (2002). Isolation of colour component from the roots of Moriunda augustifolia Roxb. and evaluation of its dyeing characteristics. Indian J. Fibre Tex. Res. 27:429-433.

[5]. Gulrajani, M. L. and Maulik, S. R. (2002). Evaluation of fastness characteristics and colour value of selected natural dyes on synthetic fibres. Tex. Trends XLV(2):31-34.

[6]. Phukan, R.; Phukan, A. and Ahmed, G. (2004). Dyeing of silk yarn with the heartwood of jackfruit. Tex. Trends XLVII:29-31.

[7]. Sengupta, S. (2001). Application of tea liqueur for colouration of cotton fabric. Tex. Trends XLIV(3):23-24. 